\title{
MEJORA EN LA CALIDAD DEL SERVICIO ¿POR DONDE EMPEZAR?
}

\author{
Enhances In The Cuality Of The Service's development. Where can we start?
}

Karen Leticia Llerena Ururi ${ }^{1}$

\author{
${ }^{1}$ Médico Cirujano Universidad Nacional de San Agustín. Arequipa, Perú \\ Médico Asistente MINSA. Jefe del Puesto de Salud Chaparra. Caraveli, Arequipa, Perú
}

\begin{abstract}
A propósito de los cambios políticos, económicos y todos los que a razón de ellos han surgido, se presenta una suerte de renovación de la atmósfera nacional con aires de optimismo en muchas esferas; con este marco de fondo, hablar de la institucionalización en los organismos estatales de lineamientos de calidad y mejora en la entrega de servicios, es una acción aplaudible que abre un nuevo reto para la comunidad que lleva a cabo la realización de los servicios, en especial la de la salud.
\end{abstract}

Hay que reconocer que medir lo que hasta hace poco parecía insondable: la percepción de la calidad de la atención de servicios de salud, ha sido un gran avance, sin embargo, la realización de esta medición llevada a cabo por los mismos trabajadores, ha hecho que se sume a su pliego de reclamos un ítem más en el apartado sobrecarga laboral; y más allá de que exista también medición de su grado de satisfacción como usuario interno, que no se busque su aplicación subraya el desinterés por mejorar las condiciones laborales.

En esta porción de trabajadores se estrellan las quejas del común de la población, descansa la exigencia en la atención y alcance de metas y coberturas, y en su condición de brazo ejecutor ¿podemos decir que hemos llegado al nudo crítico de la problemática en la salud nacional? Para nadie es desconocida la situación de lamento constante en cuanto a la salud de parte del peruano y la utilización de la palabra maltrato se ha vuelto cada vez más común de parte de los usuarios hacia el ejecutor de la acción en salud, por ello, en la búsqueda de mejoras, hablar del desabastecimiento de insumos materiales y humanos, doloroso y álgido como es, es un tema aparte y uno muy grande; en cambio, apostar por lo que en el sector privado ya se realiza, como viene siendo la mejora del clima organizacional y el enfoque de valoración al talento humano ¿rendirá resultados en nuestro contexto, y si lo hace, hasta dónde? Dice el proverbio que si algo hace relucir el carácter de una persona, son los escenarios difíciles y las acciones que tomará para hacerles frente; en este orden ¿podemos sentenciar con firmeza que si un trabajador es mediocre en circunstancias difíciles lo será igual en contextos más cómodos? No tenemos garantes desde la tribuna que apoya estas iniciativas de apreciación del trabajador ni desde la de los escépticos. Utópico, como suena esta revaloración de la persona trabajadora de salud, esta es quizá la estrategia menos ambiciosa, pero llevándose a cabo de forma correcta, tomando en cuenta que ni las materias de trabajo mínimas están garantizadas, abarcaría hasta el aseguramiento de la entrega de los insumos necesarios; sin exigencias explícitas, haría reconsiderar nuestra condición de servidores antes que trabajadores, y quien sabe reintroduciría, en algún porcentaje, esa sensibilidad humana en la actuación del proceso de restauración de la salud del enfermo, quien, a fin de cuentas, es el más afectado en este ambiente de "sensación de ser maltratado - producción de maltrato", que parece querer incluirse en el proceso enfermedad salud, que ya es de por si es complejo. 